\title{
Analisis Geospasial Area Genangan Banjir Rob dan Dampaknya pada Penggunaan Lahan Tahun 2020 - 2025 di Kota Pekalongan Provinsi Jawa Tengah
}

\author{
Syafrei Adi Iskandar ${ }^{1 *}$, Muhammad Helmi ${ }^{1}$, Muslim ${ }^{1}$, Sugeng Widada ${ }^{1}$ dan Baskoro Rochaddi ${ }^{1}$ \\ ${ }^{I}$ Departemen Oseanografi, Jurusan Ilmu Kelautan Fakultas Perikanan dan Ilmu Kelautan, \\ Universitas Diponegoro \\ Jl. Prof. Soedarto, S.H., Tembalang, Semarang 50275 \\ Email: *syafreiadi@gmail.com
}

\begin{abstract}
Abstrak
Perubahan iklim dapat menyebabkan peningkatan temperatur laut yang berdampak pada kenaikan muka air laut karena pencairan es di kutub. Naiknya muka air laut menimbulkan ancaman bagi wilayah yang berada di wilayah pesisir dan pantai, salah satunya adalah Kota Pekalongan. Salah satu dampak yang ditimbulkan adalah banjir rob. Banjir rob diakibatkan pasang air laut dan diperparah oleh fenomena kenaikan muka air laut serta penurunan muka tanah sehingga menjadi faktor dalam perluasan genangan banjir rob. Tujuan dari penelitian ini adalah melakukan pengolahan data dan mengkaji karakteristik pasang surut bulan Februari 2020 serta laju kenaikan muka air laut, mengetahui laju penurunan muka tanah berdasarkan citra Satelit SAR Sentinel-1 tahun 2017-2019 untuk rekonstruksi topografi pada tahun 2025, dan analisis luas area genangan banjir rob pada penggunaan lahan bulan Februari 2020 dan prediksi tahun 2025. Metode yang digunakan untuk komponen pasang surut dihitung dengan menggunakan metode Admiralty, kenaikan muka air laut dengan metode regresi linier, laju penurunan muka tanah dengan metode DInSAR dan pemetaan genangan banjir rob dengan pemodelan geospasial. Hasil dari penelitian ini menunjukkan nilai selisih HHWL dan MSLpada bulan Februari 2020 adalah 45,99 cm. Kenaikan muka air laut adalah 4,3 mm/tahun. Penurunan muka tanah rata-rata Pekalongan Utara, Pekalongan Barat, Pekalongan Timur, dan Pekalongan Selatan sebesar 24,13 cm/tahun, 22,83 cm/tahun, 21,94 cm/tahun, dan 20,40 cm/tahun. Luas daerah yang tergenang banjir rob pada bulan Februari 2020 dengan total 477,57 hektar. Prediksi luas area yang tergenang banjir rob tahun 2025 dengan total 1877,07 hektar. Pengaruh penurunan muka tanah menjadi faktor paling tinggi dibandingkan dengan kenaikan muka air laut terhadap perubahan luas genangan banjir rob.
\end{abstract}

Kata kunci : Banjir rob, Kenaikan muka air laut, Penurunan muka tanah, Kota Pekalongan

\begin{abstract}
Climate change can cause an increase in sea temperatures that have an impact on sea-level rise due to melting polar ice caps. Rising sea levels pose a threat to areas in coastal and coastal areas, one of which is the City of Pekalongan. One of the impacts is the tidal flood. Tidal floods are caused by tides and are exacerbated by the phenomenon of rising sea levels and land subsidence, which is a factor in the expansion of tidal flood inundation. The purpose of this study is to conduct data processing and study the characteristics of tides in February 2020 and the trend of sea-level rise, knowing the rate of land subsidence based on SAR Sentinel-1 Satellite imagery in 2017-2019 for topographic reconstruction by 2025, and analysis of tidal flood inundation areas for land use in February 2020 and prediction in 2025. The method used for the tidal component is calculated using the Admiralty method, sea-level rise with linear regression method, the rate of land subsidence using the DInSAR method, and mapping of tidal flood inundation with geospatial modeling. The results of this study indicate the value of the difference in HHWL and MSL in February 2020 is $45.99 \mathrm{~cm}$. The increase in sea level is $4.3 \mathrm{~mm} /$ year. Average land subsidence in North Pekalongan, West Pekalongan, East Pekalongan, and South Pekalongan was 24.13 $\mathrm{cm} /$ year, $22.83 \mathrm{~cm} /$ year, $21.94 \mathrm{~cm} /$ year, and $20.40 \mathrm{~cm} /$ year. The area of tidal flood in February 2020 with a total of 477,57 hectares. Prediction of the area flooded by tidal floods in 2025 with a total of 1877.07 hectares. The effect of land subsidence is the highest factor compared to sea-level rise on changes in tidal flood area.
\end{abstract}

Keywords : Tidal flood, sea-level rise, land subsidence, Pekalongan City

http://ejournal2.undip.ac.id/index.php/ijoice/

Diterima/Received : 13-08-2020

Disetujui/Accepted : 31-10-2020 


\section{PENDAHULUAN}

Indonesia adalah negara yang rentan terhadap bencana alam, terutama wilayah Jawa (Ella et al., 2016). Daerah pesisir Pulau Jawa yang sangat strategis dapat dioptimalkan untuk mendukung pelaksanaan pembangunan. Banyak perkotaan dan kawasan strategis di Indonesia yang terletak di wilayah pesisir (Cahyadi et al., 2013). Di wilayah pesisir utara Pulau Jawa khususnya di Pekalongan memiliki permasalahan banjir rob yang berdampak pada penggunaan lahan sehingga mempengaruhi dalam rencana pengelolaan tata ruang wilayah (Kabullah dan Marfai, 2014). Penelitian terdahulu yang pernah dilakukan di Pekalongan menyebutkan bahwa penggenangan banjir rob yang terjadi hampir setiap hari dengan durasi waktu genangan 3-5 jam (Sauda et al., 2019). Bencana banjir rob yang terjadi dengan intensitas tinggi dapat mengakibatkan tergenangnya daratan, rusaknya fasilitas-fasilitas umum, dan infrastruktur lainnya sehingga menyebabkan kerugian yang besar (Ritohardoyo et al., 2014). Bencana banjir rob yang diikuti dengan fenomena kenaikan muka air laut dan penurunan muka tanah berpotensi memperluas daerah tergenang banjir rob (Marfai et al., 2008). Penelitian mengenai "Analisis Geospasial Area Genangan Banjir Rob dan Dampaknya pada Penggunaan Lahan Tahun 2020 - 2025 di Kota Pekalongan Provinsi Jawa Tengah" belum dilakukan sebelumnya di daerah tersebut dengan memperhatikan faktor dari kenaikan muka air laut dan penurunan muka tanah. Banjir rob diperkirakan akan terus mengalami peningkatan baik pada frekuensi dan luas genangan dimasa mendatang (Marfai, 2013). Pengamatan daerah pesisir pantai yang luas dan perubahan yang cepat diperlukan teknologi penginderaan jauh yang dapat mempercepat proses penyediaan informasi (Kiefer dan Lillesand, 1994).

Banyak penelitian yang telah membahas tentang pemodelan genangan banjir rob, namun masih dibatasi oleh kenaikan muka air laut, penurunan muka tanah dan topografi survei lapangan yang ada di Kota Pekalongan. Berdasarkan hal ini, maka perlu dilakukan pemodelan geospasial genangan banjir serta dampaknya pada penggunaan lahan dan prediksinya sebagai informasi dasar dalam perencanaan upaya mitigasi bencana dari kenaikan muka air laut dan penurunan muka tanah yang menyebabkan masalah banjir rob di Kota Pekalongan, Jawa Tengah.

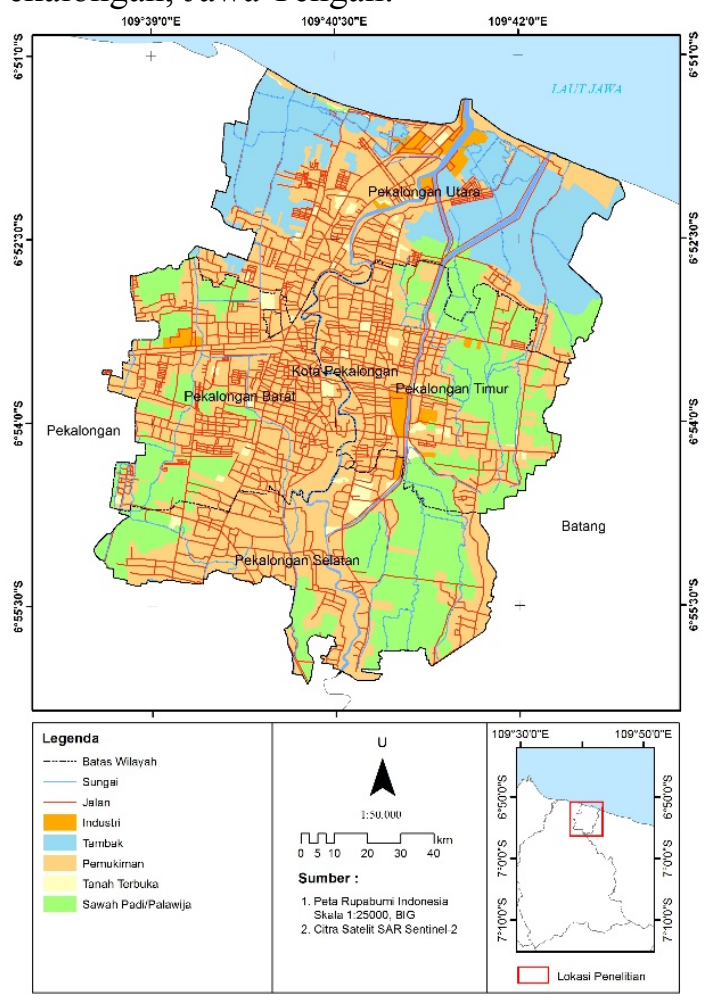

Gambar 1. Lokasi Penelitian 


\section{MATERI DAN METODE \\ Materi Penelitian}

Materi yang digunakan dalam penelitian ini meliputi data primer dan data sekunder. Data primer yaitu citra Satelit SAR Sentinel-1 (Perekaman 17 Februari 2017, 05 Oktober 2019, dan 17 Oktober 2019), citra Satelit SAR Sentinel-2 (Perekaman 29 Oktober 2019), Data Sea Level Anomaly di Perairan Pekalongan, dan data hasil survei lapangan batas genangan banjir rob terjauh. Data sekunder meliputi DTM hasil survei topografi MercyCorp Project tahun 2019, data pasang surut Kota Pekalongan hasil pengukuran BIG Februari 2020),dan Peta Rupabumi Indonesia Kota Pekalongan skala 1:25000.

\section{Metode Penelitian}

Metode yang digunakan dalam penelitian ini adalah metode kuantitatif karena telah memenuhi kaidah-kaidah ilmiah yaitu konkret, obyektif, rasional, sistematis. Metode kuantitatif memiliki karakteristik sistematis, terencana dan terstruktur dari awal hingga akhir penelitian (Suryana, 2010). Pada penelitian ini dilakukan survei pendahuluan di lokasi penelitian, kemudian pengumpulan data terkait banjir rob, setelah itu dilakukan pengolahan data yaitu pengolahan data pasang surut, pembuatan peta genangan rob. Sifat penelitian ini bersifat deskriptif, yang berarti penelitian ini dilakukan untuk memecahkan masalah dengan menjelaskan suatu obyek penelitian berdasarkan pada fakta. Penelitian deskriptif dilakukan untuk mendeskripsikan fakta, karakteristik, dan hubungan antara fenomena yang diteliti (Nazir, 2015).

\section{Metode Penentuan Batas Genangan Banjir Rob terjauh}

Penentuan batas genangan terjauh banjir rob dilakukan dengan menggunakan metode In-depth Interview. Menurut Linarwati et al. (2016), metode In-depth Interview merupakan proses memperoleh keterangan untuk tujuan penelitian dengan cara tanya jawab sambil bertatap muka antara pewawancara dengan informan atau orang yang diwawancarai, dengan atau tanpa menggunakan pedoman wawancara, pewawancara untuk memperoleh informasi mengenai titik genangan banjir rob terjauh. Penentuan lokasi batas genangan banjir rob sebanyak 26 titik menggunakan menu marking pada GPS untuk menampilkan dan menyimpan koordinat titik banjir rob yang terjadi.

\section{Metode Analisis Data}

Pasang Surut

Data pasang surut pengukuran Badan Informasi Geospasial selanjutnya dilakukan analisis harmonik dengan menggunakan metode Admiralty sehingga diperoleh suatu angka konstanta harmonik pasang surut yang meliputi Amplitudo (A), M2, S2, K1, O1, N2, K2, P1, M1, MS4. Berikut merupakan persamaan untuk mendapat nilai elevasi muka air laut dan nilai Formzahl yang pernah digunakan dalam penelitian Fadhilah et al. (2014) :

1. Mean Sea Level (MSL) $\mathrm{MSL}=\mathrm{A}\left(\mathrm{S}_{0}\right)$

2. Lowest Low Water Level (LWL) $\mathrm{LLWL}=\mathrm{A}\left(\mathrm{S}_{0}\right)-\left(\mathrm{A}\left(\mathrm{M}_{2}\right)+\mathrm{A}\left(\mathrm{S}_{2}\right)+\mathrm{A}\left(\mathrm{K}_{1}\right)+\mathrm{A}\left(\mathrm{O}_{1}\right)+\mathrm{A}\left(\mathrm{P}_{1}\right)+\mathrm{A}\left(\mathrm{K}_{2}\right) \mathrm{A}\left(\mathrm{N}_{2}\right)\right.$

3. Highest High Water Level (HHWL) $\mathrm{HHWL}=\mathrm{A}\left(\mathrm{S}_{0}\right)+\left(\mathrm{A}\left(\mathrm{M}_{2}\right)+\mathrm{A}\left(\mathrm{S}_{2}\right)+\mathrm{A}\left(\mathrm{K}_{1}\right)+\mathrm{A}\left(\mathrm{O}_{1}\right)+\mathrm{A}\left(\mathrm{P}_{1}\right)+\mathrm{A}\left(\mathrm{K}_{2}\right)+\mathrm{A}\left(\mathrm{N}_{2}\right)\right.$

4. Nilai Formzahl (F)

$$
\mathrm{F}=\frac{A K_{1}+A O_{1}}{A M_{2}+A S_{2}}
$$

Keterangan :

$\mathrm{F}=$ Konstanta Pasang Surut 
$\mathrm{AK}_{1}=$ Amplitudo anak gelombang pasut harian rata-rata yang dipengaruhi oleh deklinasi bulan dan matahari

$\mathrm{AO}_{1}=$ Amplitudo anak gelombang pasut harian tunggal yang dipengaruhi oleh deklinasi matahari

$\mathrm{AM}_{2}=$ Amplitudo anak gelombang pasut harian ganda rata-rata yang dipengaruhi oleh bulan

$\mathrm{AS}_{2}=$ Amplitudo anak gelombnag pasut harian rata- rata yang dipengaruhi oleh matahari

Menurut Mahatmawati et al. (2009) klasifikasi tipe pasang surut adalah :

$0.00<\mathrm{F}<0.25=$ Pasang surut ganda beraturan

$0.25<\mathrm{F}<1.50=$ Pasang campuran condong ke harian ganda

$1.50<\mathrm{F}<3.00=$ Pasang campuran condong ke harian tunggal

$\mathrm{F}>3.00 \quad=$ Pasang harian tunggal beraturan

Dalam hal ini untuk mengetahui area genangan banjir rob maka nilai yang digunakan adalah selisih nilai HHWL dan MSL.

\section{DTM (Digital Elevation Model)}

Data DEM merupakan data digital berformat raster yang memiliki informasi koordinat posisi $(\mathrm{x}, \mathrm{y})$ dan elevasi (z) pada setiap pixel atau selnya. DTM yang digunakan dalam penelitian ini adalah titik tinggi hasil pengolahan DSM (Digital Surface Model) citra Satelit SARSentinel-1 hasil metode InSAR (Interferometric Synthetic Aperture Radar) (Sunu et al., 2019). Data DSM tersebut selanjutnya divalidasi dengan data DTM survei lapangan tahun 2019 dengan extract multi values to point kemudian elevasinya dimasukkan ke dalam koordinat titik tinggi dan diinterpolasi dengan metode topo to raster. Menurut Indarto dan Prasetyo (2014) Topo to raster menginterpolasi nilai ketinggian untuk setiap piksel raster dengan proses interpolasi menggunakan algorithma IDW (Inverse Distance Weighting).

\section{Penurunan Muka Tanah (PMT)}

Data citra Satelit SAR Sentinel-1 dalam format Single Look Complex (SLC) rekaman 17 Februari 2017 dan 05 Desember 2019. Menurut Mura et al. (2014) pemilihan citra master dan slave berdasarkan stack overview. Proses selanjutnya dilakukan InSAR processing untuk mendapatkan interferogram dari dua citra tersebut. Interferogram tersebut menghasilkan informasi beda fase antara dua citra yang diolah.

Citra interferogram yang dihasilkan berhubungan langsung dengan bentuk topografi wilayah penelitian namun masih ada unsur deformasi, noise, dan atmosfer. Oleh karena itu, dilakukan reduksi untuk mengurangi beda fase yang dihasilkan selain deformasi. Differential Interferometry Synthetic Aperture Radar (DInSAR) dilakukan untuk menghapus unsur topografi dan image filtering. Proses DInSAR pada perangkat lunak SNAP menghasilkan jumlah total penurunan muka tanah dalam kurun waktu selang waktu akuisisi dua citra yang diolah, untuk mendapatkan laju penurunan muka tanah setiap tahunnya dihitung dengan raster calculator. Rumus untuk mendapatkan laju penurunan muka tanah per tahun adalah:

$$
\text { Velocity } \mathrm{PMT}=\frac{\text { Nilai PMT } * 365}{\text { Selang waktu akuisisi pasangan citra (dalam hari) }}
$$

\section{Kenaikan Muka Air Laut}

Kenaikan muka air laut merupakan fenomena yang terjadi secara periodik sehingga dapat dilihat melalui pasang surut yang terjadi di suatu perairan. Fenomena ini dapat diketahui kenaikannya, Analisa laju kenaikan muka air laut dengan pendekatan secara regresi linier (Cahyadi et al., 2016) Data ditampilkan dalam grafik yang kemudian dicari laju kenaikan muka air laut pertahunnya dengan metode regresi linier sebagai berikut :

$$
y=a x+b
$$


nilai y merupakan variabel tak bebas yang dicari yaitu nilai tren kenaikan muka air laut, sedangkan $\mathrm{x}$ adalah variabel bebas yaitu waktu, dalam hal ini adalah jumlah bulan. Nilai tren per tahun dapat dicari dengan persamaan yang dipakai oleh Cahyadi et al. (2016) seperti berikut :

$$
\text { tren Pertahun }=\frac{\text { Ymaksimal }- \text { Yminimal }}{\text { bulan }} \times 12 \text { bulan }
$$

\section{Model Geospasial Genangan Banjir Rob}

Pemetaan area genangan banjir rob digunakan untuk mengetahui luasan dari genangan banjir rob. Model geospasial genangan banjir pasang dibuat dengan memasukkan nilai selisih HHWL dan MSL ke dalam modul Raster Calculator. Berikut persamaan yang dimasukkan ke dalam modul tersebut seperti yang digunakan oleh Marfai et al. (2011):

$\mathrm{WD}=\operatorname{Con}(\mathrm{Con}([\mathrm{DEM}] \leq$ Elevasi,Elevasi $)$, Con([DEM] $\leq$ Elevasi,Elevasi)-[DEM $], 0)$

Keterangan:

WD : Kedalaman air genangan banjir rob

DEM : Data ketinggian tanah

Elevasi : HHWL - MSL

\section{Model Geospasial Prediksi Genangan Banjir Rob}

Pemetaan prediksi area genangan rob untuk mengetahui luasan dari genangan banjir rob dengan faktor kenaikan muka air laut dan penurunan muka tanah. Menurut Suhelmi (2012) Asumsi penurunan tanah dan kenaikan muka air laut terjadi secara linier. Data HHWL dan MSL dijadikan sebagai dasar perhitungan luas wilayah yang terkena rob. Penentuan distribusi wilayah yang terkena genangan rob dilakukan dengan menggunakan formula:

$$
\mathrm{DEMt}=\mathrm{DEM}-((\mathrm{Pt}-\mathrm{MSLt})+\mathrm{St})
$$

\section{Keterangan}

DEMt = DEM daerah tergenang pada tahun $\mathrm{t}$

DEM = DEM pengolahan titik tinggi

Pt $=$ Pasang tertinggi

MSLt $=$ Mean Sea Level pada Tahun $\mathrm{t}$

St $\quad=$ Nilai subsiden pada tahun $\mathrm{t}$

\section{HASIL DAN PEMBAHASAN}

Berikut hasil pengolahan data pengukuran pasang surut bulan Februari 2020 Kota Pekalongan.

Tabel 1. Komponen Harmonik Pasang Surut.

\begin{tabular}{ccc}
\hline koefisien & $\mathrm{A}(\mathrm{cm})$ & $\mathrm{g}^{\mathrm{o}}$ \\
\hline $\mathrm{S}_{0}$ & 140,42 & 180 \\
$\mathrm{M}_{2}$ & 11,63 & 231,18 \\
$\mathrm{~S}_{2}$ & 7,18 & 158,40 \\
$\mathrm{~N}_{2}$ & 5,34 & 174,56 \\
$\mathrm{~K}_{1}$ & 12,04 & 108,04 \\
$\mathrm{O}_{1}$ & 2,62 & 41,20 \\
$\mathrm{M}_{4}$ & 0,49 & 76,82 \\
$\mathrm{MS}_{4}$ & 0,75 & 282,12 \\
$\mathrm{~K}_{2}$ & 1,94 & 158,40 \\
$\mathrm{P}_{1}$ & 3,97 & 108,04 \\
\hline
\end{tabular}

Tipe pasang surut berdasarkan nilai $\mathrm{F}$ (Formzahl) adalah 0,77 sehingga termasuk pasang campuran condong ke harian ganda. Hasil penelitian ini sama dengan penelitian sebelumnya yang dilakukan oleh Shabari et al. (2019) yang juga memperoleh tipe pasang surut campuran condong ke harian ganda. Tipe pasang surut ini berarti bahwa satu hari terjadi dua kali air pasang dan dua kali air surut, tetapi terkadang terjadi satu kali pasang dan satu kali surut dengan memiliki tinggi dan waktu 
yang berbeda. Selain itu, didapat nilai elevasi muka air laut berupa HHWL dan MSL secara berurutan adalah 186,41 cm dan 140,42 cm. Grafik pasang surut perairan Kota Pekalongan ditunjukkan dalam Gambar 2.

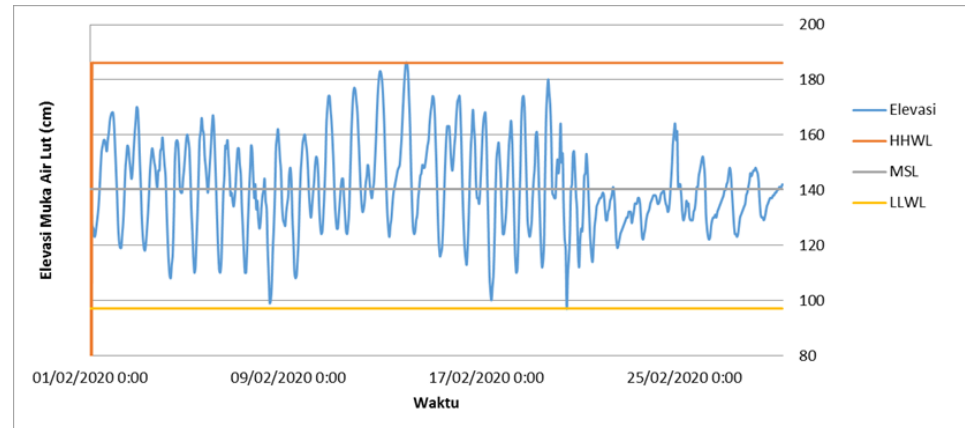

Gambar 2. Grafik Pasang Surut stasiun BIG bulan Februari 2020

Nilai elevasi muka air laut yang digunakan sebagai acuan awal untuk model geospasial genangan banjir rob merupakan selisih antara MSL dan HHWL. Sedangkan untuk membuat prediksi genangan 5 tahun mendatang, nilai tersebut ditambah dengan nilai kenaikan muka air laut dihitung dari data Sea Level Anomaly (SLA) tahunan dari tahun 1993 sampai dengan tahun 2018. Berikut merupakan grafik tren kenaikan muka air laut tahun 1993 - 2018 ditunjukkan pada gambar 3.

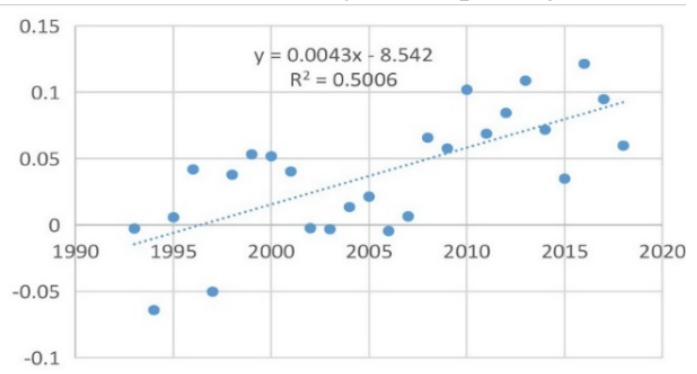

\section{Gambar 3. Sea Level Anomaly di Perairan Pekalongan}

Hasil pengolahan metode DInSAR dapat menunjukkan penurunan muka tanah di Kota Pekalongan yang besarnya penurunan muka tanah tersebut bervariasi di setiap kecamatan ditunjukkan dalam gambar 4 .

Penurunan muka tanah di Kota Pekalongan terdapat nilai tertinggi yaitu di Kecamatan Pekalongan Utara sebesar $27,51 \mathrm{~cm} /$ tahun. Rata-rata penurunan muka tanah pada kecamatan Pekalongan Utara, Pekalongan Barat, Pekalongan Timur, dan Pekalongan Selatan secara berurutan sebesar 24,13 $\mathrm{cm} /$ tahun, $22,83 \mathrm{~cm} /$ tahun, $21,94 \mathrm{~cm} /$ tahun, dan 20,40 cm/tahun. Menutut hasil pengolahan spasial oleh Ismanto et al. (2009) menyatakan bahwa semakin mendekati pantai laju penurunan tanah semakin besar karena lapisan tanah di daerah pantai merupakan lapisan tanah yang terus mengalami konsolidasi/pemampatan. Dari hasil perhitungan juga diketahui bahwa persentase laju penurunan tanah tertinggi adalah pada kelas penggunaan lahan untuk pemukiman dengan persentase 50,53\%. Faktor penurunan muka tanah ini dapat mempengaruhi dalam luas penggenangan banjir rob di masa mendatang. Hal ini sejalan dengan pernyataan Suripin dan Syafrudin (2015) bahwa luas genangan banjir rob pada kurun waktu mendatang dengan adanya faktor penurunan muka tanah maka genangan banjir rob terjadi peningkatan, dalam penelitiannya di Semarang Timur kontribusi faktor penurunan muka tanah terhadap kenaikan genangan banjir rob sebesar 1,39\% per tahun. Laju penurunan muka tanah menyebabkan peningkatan yang cukup signifikan dalam penambahan luas wilayah yang tergenang (Suhelmi, 2012). Perubahan penggunaan lahan dengan penurunan tanah menurut Koch et al. (2019) menunjukkan bahwa adanya korelasi wilayah perkotaan (kepadatan penduduk) dan luas banjir dengan 
tingkat penurunan muka tanah. Besaran penurunan muka tanah per kecamatan berdasarkan nilai ratarata, minimal dan maksimal ditunjukkan dalam tabel 2.

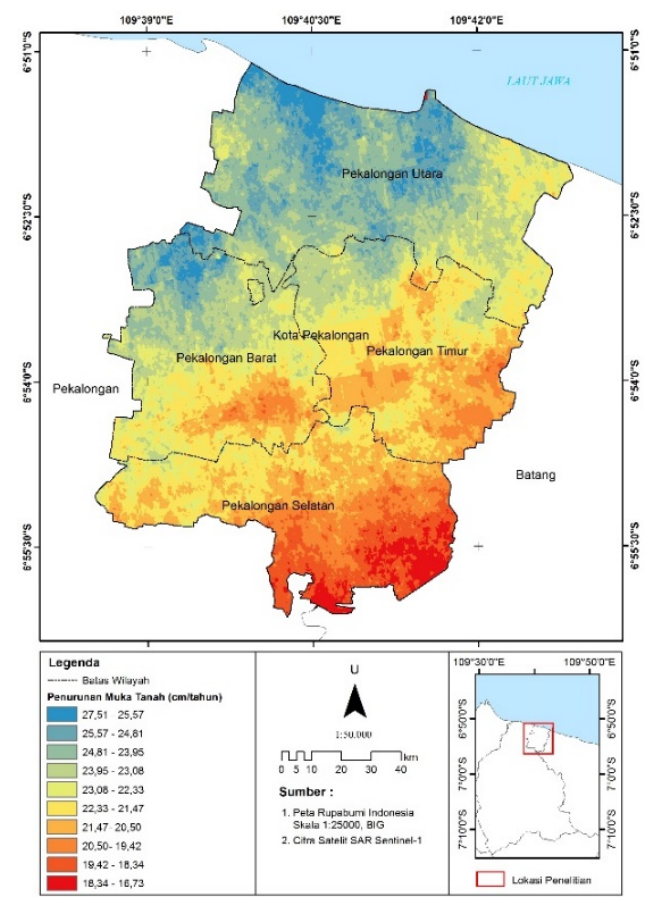

Gambar 4. Peta Penurunan Muka Tanah kota Pekalongan tahun 2017-2019

Tabel 2. Kecepatan penurunan muka tanah Kota Pekalongan tiap tahun

\begin{tabular}{llllll}
\hline No & Kecamatan & Rata-rata $(\mathrm{cm})$ & Max $(\mathrm{cm})$ & Min $(\mathrm{cm})$ & Std Dev \\
\hline 1 & Pekalongan Utara & $-24,13$ & $-27,51$ & $-19,73$ & 1,06 \\
2 & Pekalongan Barat & $-22,83$ & $-26,80$ & $-18,93$ & 1,33 \\
3 & Pekalongan Timur & $-21,94$ & $-25,64$ & $-18,57$ & 1,13 \\
4 & Pekalongan Selatan & $-20,40$ & $-24,31$ & $-16,74$ & 1,43 \\
\hline
\end{tabular}

Berdasarkan data titik tinggi yang telah diolah menjadi DTM, maka dapat diketahui representasi keadaan topografi di lokasi penelitian yang ditampilkan pada gambar 5 .

Berdasarkan hasil interpolasi didapatkan ketinggian 0 hingga 12,74 meter. Sedangkan menurut Adibah et al., (2013) menyatakan bahwa Kota Pekalongan memiliki Ketinggian antara 0-16 meter dengan kemiringan lereng antara $0-1,893718 \%$ dan termasuk dalam kelas kemiringan lereng datar $(0-$ 8\%). Perbedaan ketinggian pada penelitian ini berbeda dikarenakan nilai koherensi pasangan citra Satelit SAR Sentinel-1. Hal ini diperkuat oleh Sunu et al., (2019) menyatakan bahwa gelombang C-Band yang dibawa oleh satelit SAR Sentinel-1 tidak dapat dipantulkan dengan baik di daerah dengan vegetasi tinggi dan daerah yang tersaturasi air. Daerah yag memiliki perbedaan paling rendah pada daerah pemukiman. Hal ini disebabkan karena daerah pemukiman tidak banyak terjadi perubahan dan menghasilkan nilai koherensi yang tinggi pada pasangan citra radar. 


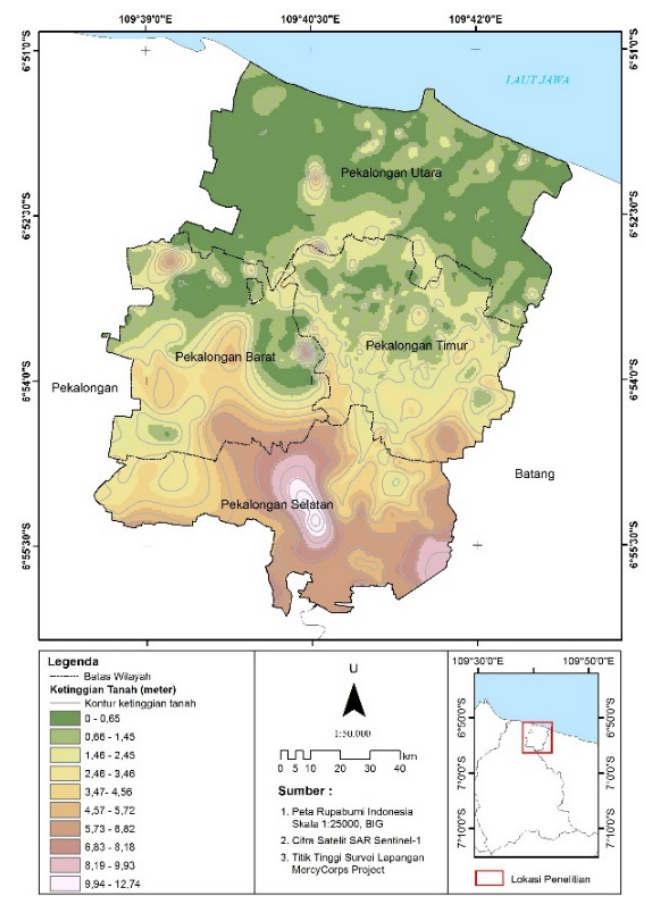

Gambar 5. Peta Ketinggian Tanah Kota Pekalongan

Hasil Titik survei lokasi genangan banjir pasang terjauh dilakukan di desa yang terkena dampak genangan banjir rob ditunjukkan pada tabel 3 .

Tabel 3. Lokasi Survei Banjir Rob Kota Pekalongan

\begin{tabular}{cllll}
\hline No & Latitude & Longitude & Kelurahan & Guna Lahan \\
\hline 1 & $-6,8841$ & 109,7112 & Degayu & Sawah \\
2 & $-6,8852$ & 109,7066 & Degayu & Sawah \\
3 & $-6,8844$ & 109,7018 & Degayu & Pemukiman \\
4 & $-6,8816$ & 109,6997 & Degayu & Jalan \\
5 & $-6,8711$ & 109,7032 & Degayu & Jalan \\
6 & $-6,8810$ & 109,6963 & Degayu & Pemukiman \\
7 & $-6,8784$ & 109,6953 & Krapyak & Sawah \\
8 & $-6,8769$ & 109,6934 & Krapyak & Sawah \\
9 & $-6,8750$ & 109,6919 & Krapyak & Sawah \\
10 & $-6,8751$ & 109,6887 & Krapyak & Pemukiman \\
11 & $-6,8721$ & 109,6800 & Krapyak & Pemukiman \\
12 & $-6,8765$ & 109,6854 & Krapyak & Pemukiman \\
13 & $-6,8726$ & 109,6778 & Panjang Wetan & Jalan \\
14 & $-6,8681$ & 109,6750 & Panjang Baru & Pemukiman \\
15 & $-6,8806$ & 109,6841 & Klego & Pemukiman \\
16 & $-6,8796$ & 109,6809 & Klego & Pemukiman \\
17 & $-6,8770$ & 109,6806 & Krapyak & Pemukiman \\
18 & $-6,8740$ & 109,6807 & Krapyak & Pemukiman \\
19 & $-6,8740$ & 109,6731 & Kandang Panjang & Jalan \\
20 & $-6,8749$ & 109,6704 & Kandang Panjang & Pemukiman \\
21 & $-6,8740$ & 109,6668 & Bandengan & Pemukiman
\end{tabular}




\begin{tabular}{lllll}
22 & $-6,8773$ & 109,6695 & Bandengan & Jalan \\
23 & $-6,8783$ & 109,6603 & Padukuhan Keraton & Pemukiman \\
24 & $-6,8766$ & 109,6649 & Padukuhan Keraton & Jalan \\
25 & $-6,8781$ & 109,6629 & Padukuhan Keraton & Pemukiman \\
26 & $-6,8778$ & 109,6577 & Padukuhan Keraton & Jalan \\
\hline
\end{tabular}

Hasil model geospasial genangan banjir rob Kota Pekalongan bulan Februari 2020 dengan acuan nilai selisih HHWL dan MSL sebesar 45,99 cm pada bulan Februari 2020. Ditunjukkan pada gambar 7.

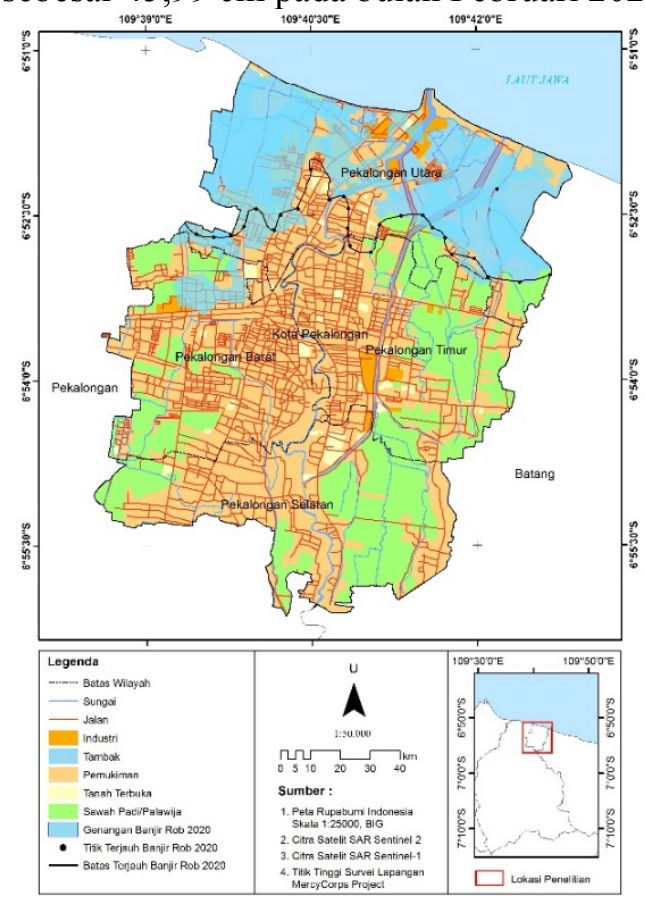

Gambar 7. Peta Genangan Banjir Rob Kota Pekalongan

Berdasarkan hasil pemodelan geospasial daerah yang mengalami banjir rob terluas adalah kecamatan Pekalongan Utara dengan luas lahan tergenang 405,64 hektar dan wilayah yang paling sedikit tergenang banjir rob yaitu Kecamatan Pekalongan Timur dengan luas 5,30 hektar. Genangan banjir rob terjadi karena topografi yang lebih rendah dari pasang tinggi tertinggi. Pasang tinggi tertinggi ini terjadi pada saat bulan purnama di setiap bulannya. Saat bulan purnama air laut mengalami pasang yang lebih tinggi dibandingkan dengan waktu lain. Hal ini dikarenakan adanya pengaruh gravitasi dari benda-benda angkasa terutama bulan dan matahari. Posisi bulan, bumi, dan matahari pada saat terjadi purnama berada pada satu garis lurus, hal ini yang mempengaruhi peningkatan elevasi muka air laut karena adanya pengaruh gaya tarik gravitasi. Total luas genangan banjir rob di Kota Pekalongan adalah 477,57 hektar. Luas penggunaan lahan yang tergenang banjir rob disajikan dalam tabel 4.

Tabel 4. Total luas wilayah yang tergenang oleh banjir rob di Kota Pekalongan bulan Februari 2020

\begin{tabular}{llcc}
\hline Kecamatan & Lahan Terdampak & Luas (Ha) & Total (Ha) \\
\hline \multirow{4}{*}{ Pekalongan Utara } & Industri & 9,66 & \\
& Pemukiman & 265,60 & \\
& Sawah Padi/Palawija & 7,72 & 405,64 \\
& Tanah Terbuka & 7,78 & \\
& Tambak & 114,89 & \multirow{2}{*}{ Pekalongan } \\
& Pemukiman & 2,71 & \\
\hline
\end{tabular}




\begin{tabular}{llcc}
\hline \multirow{3}{*}{ Pekalongan Barat } & Industri & 2,77 & \\
& Pemukiman & 53,79 & 66,64 \\
& Sawah Padi/Palawija & 10,07 & \\
\hline & Total luas lahan terdampak (Ha) & 477,57 \\
\hline
\end{tabular}

Berdasarkan pemodelan geospasial prediksi genangan banjir rob dengan faktor laju penurunan muka tanah dan tren kenaikan muka air laut ditunjukkan pada gambar 7 .

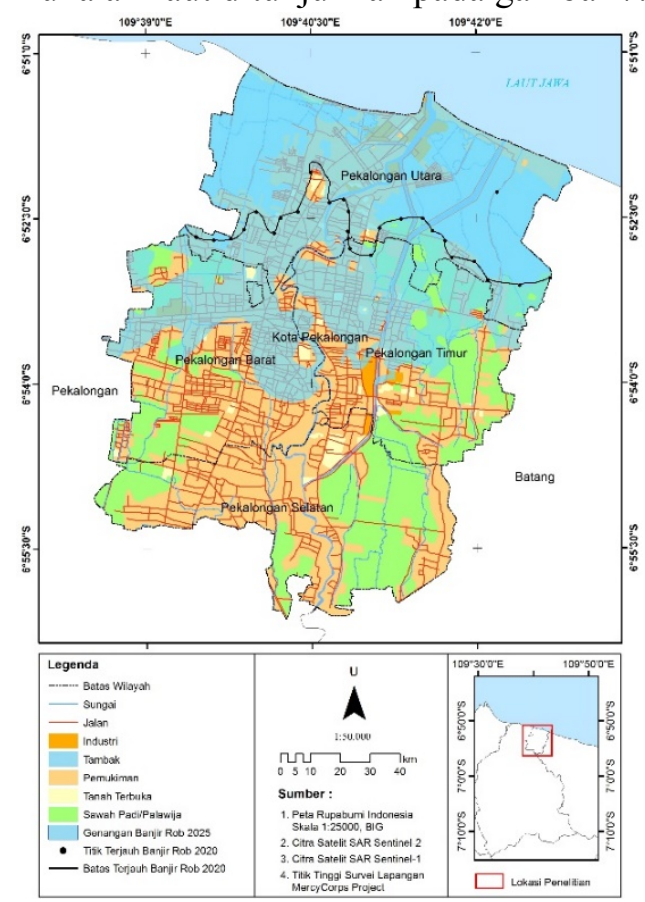

Gambar 6. Peta Prediksi Genangan Banjir Rob Kota Pekalongan tahun 2025

Luas masing-masing kecamatan yang tergenang banjir rob serta dampaknya pada penggunaan lahan pada tahun 2025 disajikan dalam tabel 5 .

Tabel 5. Total luas wilayah yang tergenang oleh banjir rob di Kota Pekalongan tahun 2025

\begin{tabular}{clcc}
\hline Kecamatan & Lahan Terdampak & Luas (Ha) & Total (Ha) \\
\hline & Industri & 42,57 & \\
& Pemukiman & 579,49 & \\
Pekalongan Utara & Sawah Padi/Palawija & 89,23 & 1024,52 \\
& tanah terbuka & 18,81 & \\
& Tambak & 294,41 & \\
Pekalongan Timur & Industri & 6,57 & 454,36 \\
& Pemukiman & 284,32 & \\
& Sawah Padi/Palawija & 156,87 & \\
& tanah terbuka & 6,61 & 398,20 \\
\hline \multirow{2}{*}{ Pekalongan Barat } & Industri & 12,13 & \\
& Pemukiman & 315,94 & \\
& Sawah Padi/Palawija & 66,61 & \\
& tanah terbuka & 3,52 & \\
\hline
\end{tabular}


Berdasarkan hasil perubahan total luas genangan banjir rob tiap kecamatan di Kota Pekalongan ditunjukkan pada gambar 8 .

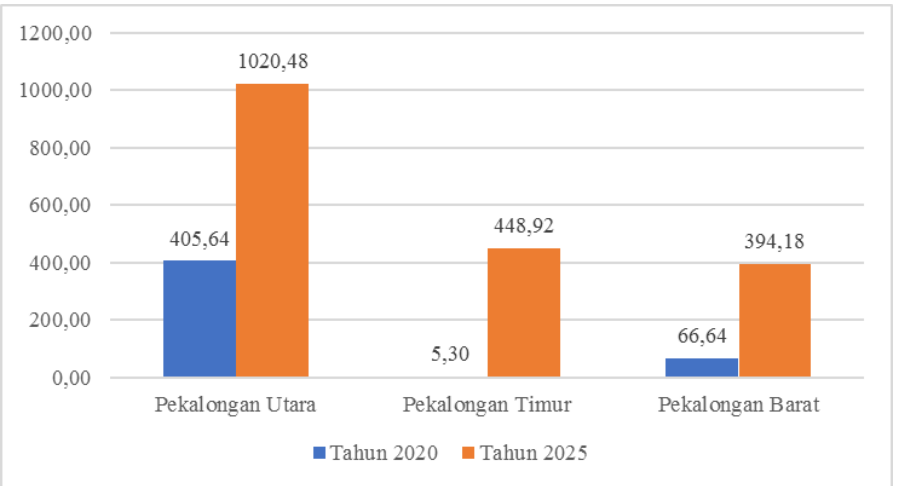

Gambar 7. Total wilayah yang tergenang oleh banjir rob di Kota Pekalongan tahun 2020 dan tahun 2025.

Berdasarkan pemodelan geospasial prediksi banjir rob di Kota Pekalongan terjadi perubahan luas pada tahun 2020 dengan luas 477,57 Hektar menjadi 1877,07 hektar pada tahun 2025. Perubahan luas daerah tergenang ini disebabkan oleh pengaruh penurunan muka tanah dan kenaikan muka air laut. Pengaruh penurunan muka tanah terhadap genangan banjir rob menjadi faktor yang paling tinggi pengaruhnya dibandingkan kenaikan muka air laut karena rata-rata laju penurunan muka tanah tertinggi yang terjadi di Kecamatan Pekalongan Utara, Kecamatan pekalongan Barat, Kecamatan Pekalongan Timur, dan Kecamatan Pekalongan Selatan berturut-turut adalah 24,13 cm/tahun, 22,83 cm/tahun, 21,94 $\mathrm{cm} / \mathrm{tahun}$, dan 20,40 $\mathrm{cm} /$ tahun sedangkan laju kenaikan muka air laut hanya $4,3 \mathrm{~mm} / \mathrm{tahun}$. Hal ini diperkuat oleh Islam et al. (2017) yang menyatakan bahwa adanya perluasan area banjir rob menunjukkan adanya korelasi antara penurunan muka tanah dengan banjir rob terutama pada wilayah yang mengalami penurunan muka tanah tertinggi. Elevasi muka air laut yang lebih tinggi akan menyebabkan run up yang lebih jauh sehingga daerah genangan yang diakibatkannya akan semakin luas dan semakin jauh ke arah daratan (Habibie et al., 2012). Dengan adanya perluasan banjir rob yang terjadi menurut Kartika dan Helmi (2019) terjadinya daerah tergenang banjir secara permanen sehingga terbentuk suatu adaptasi dengan meninggikan lantai rumah dan pembangunan tanggul setinggi 3 meter dengan panjang sampai 7,2 km yang diharapkan cukup efektif untuk mengatasi banjir rob.

\section{KESIMPULAN}

Berdasarkan data pasang surut pada bulan Februari 2020, tipe pasang surutnya adalah pasang campuran condong ke harian ganda dengan nilai Formzahl (F) adalah 0,77 serta laju kenaikan muka air laut sebesar 4,3 mm/tahun. Laju penurunan muka tanah berkisar $16,74 \mathrm{~cm} /$ tahun $27,51 \mathrm{~cm} /$ tahun. Sehingga didapatkan hasil pemodelan geospasial genangan banjir rob tahun 2020 dengan luas 477,57 hektar dan prediksi genangan banjir rob pada tahun 2025 dengan luas 1877,07 hektar.

\section{DAFTAR PUSTAKA}

Adibah, N., Kahar S., dan Sasmito B. 2013. Aplikasi Penginderaan Jauh dan Sistem Geografi untuk Analisis Daerah Resapan Air (Studi Kasus: Kota Pekalongan). Jurnal Geodesi Undip., 2(2): 2337-845.

Cahyadi, A., Marfai, M. A., Mardiatno, D., dan Nucifera, F. 2013. Pemodelan Spasial Bahaya Banjir Rob Berdasarkan Skenario Perubahan Iklim dan Dampaknya di Pesisir Pekalongan. Jurnal bumi Lestari., 3(2): 244-256.

Cahyadi, N. M., M. J. Lalu, dan H. D. Aryansandah. 2016. Studi Kenaikan Muka Air Laut Menggunakan Data Satelit Altimetri Jason-1 (Studi Kasus: Perairan Semarang). Jurnal Geoid., 11(2): 176-183. 
Church, J. A., dan White N. J. 2011. Sea-level rise from the late 19th to the early 21 st century. Surveys in geophysics., 32(4-5): 585-602.

Ella, R., dan Saputra R. 2016. Floo-prone Areas Mapping at Semarang City By Using Simple Additive Weighting Method. Procedia-Social and Behavioral sciences., 227: 378-386.

Habibie, M.N., Agus H., Nining S.N., Muhammad H., Siswanto., Roni K., Andri R., dan Rahayu S. D. 2012. Simulasi Rob Semarang menggunakan Model Hidrodinamika 2D. jurnal meteorology dan geofisika., 13(2): 103-109.

Ismanto, A., Wirasatriya, A., Helmi, M., Hartoko, A., dan Prayogi, P. 2009. Model Sebaran Penurunan Tanah di Wilayah Pesisir Semarang. International Journal of Marine Sciences (IJMS)., 14(4), 189-196.

Kartika, F. D. S., dan Helmi, M. 2019. Meta-analysis of community's adaptation pattern with tidal flood in Pekalongan City, Central Java, Indonesia. In E3S Web of Conferences., Vol. 125, p. 09001. EDP Sciences.

Kiefer, R.W., dan Lillesand T. M. 1994. Remote sensing and image interpretation. University of Gajah Mada University Press. Bulaksumur, Yogyakarta.

Koch, M., Gaber, A., Darwish, N., Bateman, J., Gopal, S., dan Helmi, M. 2019. Estimating Land Subsidence in Relation to Urban Expansion in Semarang City, Indonesia, Using InSAR and Optical Change Detection Methods. In IGARSS 2019-2019 IEEE International Geoscience and Remote Sensing Symposium., 2153-7003: 9686-9689

Linarwati, M., Fathoni, A., dan Minarsih, M. M. 2016. Studi deskriptif pelatihan dan pengembangan sumberdaya manusia serta penggunaan metode behavioral event interview dalam merekrut karyawan baru di bank mega cabang kudus. Journal of Management, 2(2): 2502-7689.

Mahatmawati, A. D., Efendy, M., dan Siswanto, A. D. 2009. Perbandingan Fluktuasi Muka Air Laut Rerata (MLR) di Perairan Pantai Utara Jawa Timur dengan Perairan Pantai Selatan Jawa Timur. Jurnal Kelautan: Indonesian Journal of Marine Science and Technology., 2(1): 1907-9931.

Marfai, M.A. 2013. Banjir Pesisir : Kajian Dinamika Pesisir Semarang. Gadjah Mada, Yogyakarta.

Marfai, M. A., Pratomoatmojo, N. A., Hidayatullah, T., Nirwansyah, A. W., dan Gomaeruzzaman, M. 2011. Model Kerentanan Wilayah Pesisir Berdasarkan Perubahan Garis Pantai dan Banjir Pasang (Studi Kasus: Wilayah Pesisir Pekalongan). RedCarpet Studio. Yogyakarta.

Nazir, M. 2003. Metode Penelitian. Ghalia Indonesia. Bandung, $622 \mathrm{hlm}$.

Pickering, M. D., Horsburgh, K. J., Blundell, J. R., Hirschi, J. M., Nicholls, R. J., Verlaan, M., dan Wells, N. C. 2017. The impact of future sea-level rise on the global tides. Continental Shelf Research, 142, 50-68.

Sauda, R.H., Arief L.N dan Hani'ah. 2019. Kajian Pemetaan Kerentanan Banjir Rob di Kabupaten Pekalongan. Jurnal Geodesi Undip., 8(1): 2337-845.

Shabari, A.R., Alfi S. dan Warsito A. 2019. Padatan tersuspensi yang dipengaruhi oleh proses Pasang Surut di Perairan Kaliboyo, Kabupaten Pekalongan. Journal of Marine Research., 8(4): 24077690.

Suhelmi, I.R. 2012. Kajian Dampak Land Subsidence Terhadap Peningkatan Luas Genangan Rob di Kota Semarang. GEOMATIKA., 18(1).

Sunu, H. A., Yuwono B.D., dan Suprayogi A. 2019. Analisis Ketelitian DSM Kota Semarang Dengan Metode InSAR Menggunakan Citra Sentinel-1. Jurnal Geodesi Undip., 8(3): 17-26.

Suripin, S., dan Syafrudin S. 2015. Pengaruh Land Subsidence terhadap Genangan Banjir dan Rob di Semarang Timur. Media Komunikasi Teknik Sipil., 21(1): 1-12.

Suryana. 2010. Metodologi Penelitian. Buku Ajar Perkuliahan. Universitas Pendidikan Indonesia, Bandung. $58 \mathrm{hlm}$. 